\title{
ANALISIS KEPRIBADIAN TOKOH MARNI KAJIAN PSIKOLOGI SIGMUND FREUD DALAM NOVEL ENTROK KARYA OKKY MADASARI
}

\author{
Ririn Setyorini \\ Universitas Peradaban Bumiayu \\ Ririnsetyorini91@gmail.com
}

\begin{abstract}
Abstrak
Sastra, terutama novel, tidak jauh dari bicara soal kehidupan bermasyarakat. Kehidupan bermasyarakat memiliki kaitan yang kuat terhadap kepribadian yang berhubungan dengan psikologi seseorang. Marni adalah salah satu tokoh utama dalam novel Entrok karya Okky Madasari. Kisah kehidupan Marni dalam novel tersebut sangatlah pelik sehingga sangat menarik untuk diteliti. Salah satu yang menarik untuk diteliti dari tokoh utama novel Entrok ini adalah kepribadian dari tokoh Marni. Penelitian ini merupakan penelitian deskriptif kualitatif. Data dalam penelitian ini berupa paragraf yang terdapat dalam novel Entrok Karya Okky Madasari dan sumber data novel dan buku acuan yang berkenaan dengan penelitian. Teknik sampling yang digunakan adalah purposive sampling. Teknik pengumpulan data dengan 2 teknik yaitu teknik baca, dan teknik catat. Teknik validitas data dalam penelitian ini dengan triangulasi data. Teknik analisis data dala penelitian ini adalah dengan analisis isi. Tujuan dari penelitian ini adalah mengetahui aspek kepribadian tokoh Marni dalam novel Entrok karya Okky Madasari berdasarkan teori kepribadian psikologi Sigund Freud. Hasil dari penelitian ini adalah tokoh Marni tersebut memiliki aspek kepribadian yang mengacu pada teori Sigmund Freud yaitu id, ego, superego.
\end{abstract}

Kata Kunci: Psikologi sastra, kepribadian, Sigmund Freud, novel, Entrok.

\begin{abstract}
As a literary work, a novel is greatly similar to the expression of a social life that is particularly strongly related to a person's personality. Marni is a protagonist of Entrok novel by Okky Madasari. She experiences a complicated life, so the literary work needs to be researched for her interesting personality. The study aims at describing a protagonist's personality (physiological aspect). The research used a descriptive-qualitative approach. The data included the paragraphs and the data source was the Entrok novel by Okky Madasari. It employed a purposive technique; the data gathering technique used a content analysis; and the data validity technique applied a theory and source/data triangulation. The result of the study shows that as a protagonist, Marni takes the personality aspects that comprise id, ego, and superego. These are line with Sigmund Freud's theory.
\end{abstract}

Keywords: Literature psychology, personality, Sigmund Freud, novel, Entrok 


\section{Pendahuluan}

Psikologi sastra adalah telaah karya sastra yang diyakini mencerminkan proses dan aktivitas kejiwaan (Minderop, 2013, p. 52). Dalam menelaah suatu karya psikologis hal yang perlu dipahami adalah sejauh mana keterlibatan psikologi pengarang dan kemampuan pengarang menampilkan para tokoh rekaan yang terlibat dengan masalah kejiwaan.

Karya sastra yang dikaitkan dengan psikologi penting untuk diteliti, sebab menurut Wellek dan Warren (1993, p. 108) bahwa psikologi membantu dalam mengumpulkan kepekaan peneliti pada kenyataan, mempertajam kemampuan, pengamatan, dan memberi kesempatan untuk mempelajari pola-pola yang belum terjamah sebelumnya. Sebagai gejala kejiwaan, psikologi dalam sastra mengandung fenomena-fenomena yang tampak lewat perilaku tokoh-tokohnya.

Tujuan psikologi sastra adalah memahami aspek-aspek kejiwaan yang terkandung dalam karya sastra. Meskipun demikian, bukan berati bahwa analisis psikologis sastra sama sekali terlepas dari kebutuhan masyarakat sesuai dengan hakikat karya sastra memberikan pemahaman kepada masyarakat secara tidak langsung melalui pemahaman tokoh-tokohnya (Ratna, 2009, p. 342).

Freud mengemukakan bahwa tujuan psikoanalisis adalah memperkuat ego, membuatnya lebih lebih independen dari superego, memperlebar medan persepsinya, memperluas organisasinya sehingga ia dapat memiliki bagian-bagian yang segar dari id. Metode-metode utama yang digunakan Freud untuk mencapai tujuan psikoloanalisis tersebut adalah (1) penggunaan asosiasi bebas secara sistematis dan analisis mimpi, (2) analisis resistensi, (3) analisis transfereni, dan (4) interpretasi dengan tujuan memecahkan masalah-masalah emosional yang utama pada masa kanak-kanak (Semiun, 2010, p. 16-17).

Koentjaraningrat (dalam Sobur, 2013, p. 301) menyebut kepribadian atau personality sebagai susunan unsur-unsur akal dan jiwa yang menentukan perbedaan tingkah laku atau tindakan dari tiap-tiap individu manusia. Dalam kehidupan sehari-hari, kata kepribadian digunakan untuk menggambarkan: (1) identitas diri, jati diri seseorang. (2) kesan umum seseorang tentang diri atau orang lain, dan (3) fungsi-fungsi kepribadian yang sehat atau bermasalah (LN Syamsu dan Nurihsan, 2008, p. 1).

Novel Entrok menceritakan perjalanan hidup Marni dan Rahayu sebagai tokoh utama, dalam penelitian ini tokoh yang akan dianalisis yaitu Marni. Marni adalah seorang Ibu yang membesarkan Rahayu di tengah perubahan zaman dan pergantian tampuk kekuasaan dari Soekarno ke Soeharto. Cerita dalam novel ini diawali dengan kisah Marni yang beranjak remaja yang menginginkan sebuah Entrok seperti milik saudaranya. Namun, harganya yang begitu mahal membuatnya sulit membelinya karena pada masa itu entrok merupakan barang mewah yang tidak semua orang bisa membelinya. Keinginan Marni yang begitu kuat menonjolkan bagaimana kepribadian yang ada di dalam dirinya.

Ulasan mengenai cerita dalam novel Entrok banyak memiliki nilai serta pribadi seorang Marni yang begitu memiliki karakter kuat menjadi alasan untuk meneliti novel ini dari segi kepribadian.

Tujuan dari penelitian ini adalah mendeskripsikan dan menjelaskan aspek kepribadian tokoh utama dalam novel Entrok, berdasarkan teori kepribadian psikologi Sigund Freud.

Penelitian ini relevan dengan penelitian yang dilakukan oleh Graham Ingham (2007) dengan judul "The superego, narcissism and Great Expectations" yang membahas tentang kepribadian dan terfokus pada superego. Ingham mencatat bahwa konsep superego dan narsisme yang terkait pada saat pembuahan dan superego patologi dapat dilihat sebagai faktor penentu dalam pembentukan gangguan narsistik; sehingga pemeriksaan superego 
dapat berfungsi sebagai 'biopsi', yang menunjukkan kondisi kepribadian secara keseluruhan. Persamaan dengan penelitian ini adalah sama-sama membahas mengenai kepribadian atau superego yang terdapat dalam tokoh novel. Perbedaan penelitian ini adalah penelitian Ingham menggunakan novel Great Expectations Charles Dickens, sedangkan penelitian ini menggunakan novel Entrok.

Penelitian ini juga relevan dengan penelitian yang dilakukan oleh Yamin Liang (2011) dengan judul "The Id, Ego and Super-ego in Pride and Prejudice" yang membahas tentang kepribadian, yaitu id, ego, dan superego yang ada dalam karakter utama novel Elizabeth. Persamaan dengan penelitian ini adalah sama-sama menganalisis kepribadian yaitu id, ego, dan superego. Penelitian yang dilakukan oleh Liang juga menggunakan objek kajian novel. Perbedaannya adalah penelitin yang dilakukan oleh Liang menggunakan novel Elizabeth dan penelitian ini menggunakan novel Entrok sebagai objek kajiannya.

\section{Metode Penelitian}

Penelitian ini merupakan penelitian deskriptif kualitatif dengan data berupa paragraf yang terdapat dalam novel. Metode yang digunakan adalah metode kepustakaan, yaitu mengumpulkan data dengan membaca buku-buku yang relevan dengan penelitian ini. Sumber data yang digunakan adalah novel Entrok dan buku-buku yang mengacu pada penelitian. Teknik sampling yang digunakan adalah purposive sampling, dan teknik pengumpulan data dengan 2 teknik yaitu teknik baca dan cata. Trianggulasi yang digunakan dalam penelitian ini adalah trianggulasi data dan teori. Teknik analisis data dalam penelitian ini adalah analisis isi dengan menggunakan pendekatan psikologi sastra teori dari Sigmund Freud sebagai alat untuk menganalisa.

\section{Hasil Penelitian dan Pembahasan}

Dalam sebuah cerita, tokoh-tokoh tersebut baik tokoh utama atau tokoh bawaan pasti memiliki kepribadian yang ada pada dirinya. Novel Entrok karya Okky Madasari merupakan novel yang begitu kuat dalam menggambarkan kepribadian dari sang tokoh utama yaitu Marni. Kepribadian yang ada dalam tokoh utama tersebut dikupas dengan teori dari Sigmud Freud, yaitu id, ego, dan superego. Berikut ini klasifikasi aspek kepribadian yang dimiliki oleh tokoh utama dalam novel Entrok karya Okky Madasari.

\subsection{Id}

Aspek id yang terdapat dalam tokoh Marni muncul sedari Marni kecil/ di awal cerita, yaitu ketika Marni menginginkan membeli entrok seperti yang ditunjukan oleh Tinah saudaranya. Keinginan Marni tersebut menjadi latar belakang kemunculan id/ naluri dalam diri Marni. Keinginan Marni bukan tidak beralasan, tentu ada alasan yang Marni kemukakan terutama kepada Simboknya meski Marni tetap tak mendapatkan entrok tersebut. Namun, karena pada era tersebut entrok adalah barang yang mewah, tentu Marni tidak semudah itu mendapatkannya, berbagai cara Marni lakukan demi mendapatkan entrok untuk menutupi dadanya. Hal tersebut terlihat dalam kutipan sebagai berikut.

"ini entrok" kata Tinah. Di kali Singget, saat kami mandi, Tinah menunjukan entroknya. Ada dua segitiga yang bisa menutup gumpalan dada. Ukurannya pas dan agak menekan. Entrok itu menekan dada Tinah sehingga tetap kencang, tidak nglawer-nglawer, meskipun dia berlari kencang atau melompat. Aku juga ingin memilikinya. Pada Simbok, kukatakan keinginanku (hlm. 17).

Kutipan tersebut menunjukan ketika Marni mulai ingin memiliki entrok, id/ nalurinya berjalan dilihat dari kerja keras Marni yang begitu menginginkan entrok tersebut hingga ia 
meminta ke sana-ke mari untuk dapat memiliki entrok. Marni lalu mendatangi Simbok untuk meminta entrok padanya. Hal tersebut terlihat dalam kutipan sebagai berikut.
"Mbok, aku mau punya entrok."
"entrok itu apa, Nduk?"
"Itu lho Mbok, kain untuk menutupi susuku supaya kencang. Seperti punya Tinah."
Simbok malah tertawa ngakak. Lama tak keluar jawaban yang aku tunggu. Hingga akhirnya dia akhiri dengan mata memerah.
"Oalah Nduk, seumur-umur tidak pernah aku punya entrok juga tidak apa-apa. Susuku tetap bisa diperas to. Sudah, nggak usah neko-neko. Kita bisa makan saja syukur.” Kata Simbok (hlm. 17).

Kutipan tersebut menunjukan id Marni muncul disetiap harinya, keinginan Marni untuk membeli entrok semakin hari semakin menjadi seolah entrok menjadi kebutuhan wajib untuk dirinya. Tak mendapatkan entrok dari Simbok, Marni lalu meminta kepada Paklik Marni atau ayah Tinah. Hal tersebut terlihat dalam kutipan berikut.

Demi entrok, aku kerumah Tinah, menemui Paklik.

"Paklik, aku pengin punya entrok kayak punya Tinah", kataku.

Paklik yang sedang duduk bersama istrinya tertawa terbahak mendengar kata-kataku.

Sama seperti reaksi Simbok saat aku minta entrok.

"Nduk, entrok itu mahal. Mbok mending duitnya buat makan," kata Paklik.

"kalau mau punya, ya minta bapakmu sana," lanjut istrinya.

"Aku tidak punya Bapak, Bulik. Aku tidak tau di mana dia, ”jawabku bergetar. Mataku mulai berkaca-kaca.

"Ya, makanya itu. Kalau sudah tahu bapak saja nggak punya, ya sudah. Nggak usah neko-neko. Bisa makan tiap hari saja sudah syukur,” (hlm. 19).

Kutipan tersebut menunjukan ketika Marni mengemukakan keinginannya kepada Pakliknya, namun apa daya jawaban yang diberikan oleh Paklik Marni sama dengan yang diberikan leh Simbok, malah lebih menyakitkan bagi Marni dari pada jawaban dari Simbok. Jawaban dari keduanya tidak membuat $\mathrm{Id} /$ naluri keinginginannya membeli entrok dia berencana untuk membeli sendiri dengan jalan mencari uang sendiri. Hal tersebut terlihat dalam kutipan sebagai berikut.

Aku tak bicara soal entrok kepada Simbok. Aku hanya berkata ingin membantunya mengupas singkong, siapa tau bisa dapat uang. Simbok berkata, aku tak akan mendapatkan uang. Kebiasaan di pasar, buruh-buruh perempuan diupahi dengan bahan makanan. Beda dengan kuli laki-laki yang diupahi dengan uang (hlm. 22).

Kutipan tersebut menunjukan ketika Marni ingin memenuhi id/ nalurinya untuk embeli entrok, dia berencara untuk membantu Simboknya agar mendapat upah. Marni meminta pada Simbok untuk ikut dia ke pasar, namun Simbok tak mengijinkan, Marni tetap memaksa kepada Simbok untuk ikut dia ke pasar membantunya. Hal tersebut terlihat dalam kutipan sebagai berikut.

Aku terdiam setengah kecewa. Tapi aku tetap memaksa ikut ke pasar. Aku bilang pada Simbok, tak apalah kita kupas singkong diupahi singkong. Paling tidak kalu ikut 
membantu, singkong yang kita bawa pulang bisa semakin banyak. Gaplek yang kita punya bisa makin banyak. Kita bisa makan lebih banyak dan jadi kenyang.

Simbok mebiarkan aku ikut ke pasar. Aku berpikir bagaimana caranya menukar upah dengan entrok (hlm. 23).

Kutipan tersebut menunjukan Marni adalah seorang yang keras kepala, terlihat dari sikapnya yang meski tidak diperbolehkan oleh Simboknya, Marni memaksa untuk ikut Simbok ke pasar. Sampai suatu ketika Marni merasa dadanya semakin membesar dan Marni semakin tidak nyaman dengan keadaannya tersebut. Keinginan Marni semakin besar untuk memiliki entrok. Hal tersebut dapat dilihat dalam kutipan sebagai berikut.

Dadaku kian membesar dan mengencang setelah aku mengeluarkan darah perta kali. Aku makin teringat entrok. Makin besar keinginanku untuk mendapatkan barang itu. Tapi bagaimana caranya?

Kutimang-timang upahku hari ini, delapan singkong. Simbok mendapat sepuluh singkong. Aku berpikir upah yang didapat Teja, si kuli di pasar, setiap hari. Teja mendapat satu rupiah untuk setiap barang yang diangkatnya. Kalau sehari dia bolak-balik mengangkat sepuluh kali, dia sudah mendapat sepuluh rupiah. Lima hari berkerja, uang Teja cukup untuk membeli satu entrok. Kenapa aku tidak bekerja seperti Teja? (hlm. 33).

Kutipan tersebut menunjukan ketika id Marni semakin besar untuk memiliki entrok, hari itu Marni pulang dari pasar setelah ia membantu Simbok bekerja di pasar mengupas singkong. Di dalam pasar Marni bertemu dengan Teja, kuli panggul di pasar. Marni berencana untuk ikut nguli bersama Teja. Id Marni semakin menjadi ketika Marni ingin memiliki entrok yang berenda agar semua orang kagum padanya. Hal tersebut terlihat dalam kutipan sebagai beikut.

Pagi itu bangun setengah kecewa. Segala keindahan dan kebahagiaan itu kenapa hanya ada dalam mimpi? Aku ingin "punya entrok berenda. Entrok sutra bertatahkan intan dan permata. Aku ingin semua orang kagum, menatapku dengan iri. Aku juga ingin semua orang yang membuatku merasa begitu bahagia. Mengantarkanku ke kerajaan yang indah (hlm. 41).

Kutipan tersebut menunjukan ketika Marni mulai berkeinginan lebih, yaitu ngin memiliki entrok berenda hingga sampai masuk ke dalam mimpi Marni. Keinginannya tersebut begitu menggebu-gebu sampai ia terus memikirkan bagaimana caranya mendapatkan uang yang banyak untuk membeli entrok tersebut. Hal tersebut terlihat dalam kutipan sebagai berikut.

Kumainkan uang-uang itu dengan kedua tanganku, sementara pikiranku berkenala. Apa lagi kalau bukan ke mimpiku. Aku harus punya banyak uang untuk membeli banyak entrok yang berenda dan yang berhiaskan emas permata (hlm. 42).

Kutipan tersebut menunjukan ketika Marni berkhayal untuk mendapatkan uang yang lebih banyak untuk membeli entrok yang beraneka ragam. Selain keinginannya mendapatkan entrok, Marni juga mempunyai keinginan untuk dapat menikahkan anaknya Rahayu secara besar-besaran. Hal tersebut terlihat dalam kutipan sebagai berikut. 
Malam Sabtu Pahing, pernikahan itu dilaksanakan. Sudah habis semua omonganku, tapi tak ada gunanya. Teja yang biasanya tak pernah ikut campur, kali ini sudah mewanti-wanti anaknya. Lha siapa yang tidak mau anak perempuannya mant besarbesaran. Sama dengan aku, Teja juga takut nanti kena karma itu berbalik pada Rahayu. Tapi, ya sudahlah. Wong yang milih dia sendiri (hlm. 166).

Kutipan tersebut menunjukan ketika Marni memiliki keinginan untuk menikahkan anknya dengan adat yang biasa dilakukan di desa Singget dan secara besar-besaran seperti pernikahannya dengan Teja.

\subsection{Ego}

Sebagai manusia biasa Marni juga memiliki ego dalam dirinya. Egonya tersebut muncul ketika Marni menentang adat dan kodrat demi mendapatkan entrok. Marni ingin bekerja sebagai kuli di pasar sedangkan Simbok Marni beranggapan bahwa kodrat dari wanita bekerja hanya cukup mengupas singkong atau berdagang. Namun ego membuatnya tetap memaksa Marni untuk bekerja sebagai kuli di pasar. Hal tersebut terlihat dalam kutipan sebagai berikut.

Pagi itu kami berangkat ke pasar, tanpa menyinggung rencanaku nguli. Simbok sudah yakin aku tak akan melakukan hal yang ra ilok. Padahal dalam hati aku tetap bertekad akan nguli. Akan kutinggakan Simbok saat dia sibuk mengupas singkong-singkong Nyai Daimah. Aku akan pergi sebentar. Setiap selesai ngangkat barang, aku akan kembali sebentar mengupas singkong. Simbok lalu akan mengira aku kebelet atau bermain dengan anak-anak (hlm. 35).

Kutipan tersebut menunjukan bahwa Marni memaksakan kehendaknya dengan menjadi kuli di pasar. Padahal hal tersebut bertentangan dengan kodrat wanita dan juga adat di desa tersebut. Tak hanya Simbok yang melarang Marni menjadi kuli, namun Mbah Noto juga melarangnya. Mbah Noto beranggapan bahwa bekerja sebagai kuli adalah pekerjaan yang berat, yang hanya bisa dilakukan oleh laki-laki dan perempuan tidak patut bekerja berat seperti yang Marni lakukan. Mbah Noto berkata bahwa perempuan hanya boleh bekerja yang halus-halus dan enteng tidak patut nguli. Hal tersebut terlihat dalam kutipan sebagai berikut.

Aku tertawa dalam hati saat mendengan nasihat Mbah Noto. Memang benar, di pasar ini tidak ada perempuan yang nguli, pekerjaan berat yang menggunakan tenaga besar. Di pasar ini, buruh perempuan mengerjakan pekerjaan yang halus dan enteng, seperti mengupas singkong, menumbuk adi, atau menumbuk kopi. Tapi coba lihat, begitu buruh-buruh perempuan itu sampai di rumah. Mereka harus mengerjakan semua pekerjaan yang ada, mengambil air dari sumber dengan menempuh perjalanan naik-turun. Berat satu jun yang berisi penuh air sama saja dengan satu goni berisi singkong. Tidak ada laki-laki yang mengambil air, katanya itu urusan perempuan. Yang jelas lebih enak nguli daripada ngambil air (hlm. 37).

Kutipan tersebut menunjukan ketika Marni tidak sejutu dengan pernyataan yang diungkapkan oleh Mbah Noto. Marni berpikir bahwa menjadi kuli dan mengambil air dengan jun dengan perjalanan naik turun ke sumber air adalah hal yang sama saja. Mengambil air dengan jun adalah tugas perempuan sedangkan berat air tersebut sama seperti satu goni singkong. Hal tersebut membuat Marni semakin betah dengan pekerjaannya sebagai kuli 
karena bisa mendapatkan uang. Setelah cukup uang dan Marni telah membeli entrok yang dia idam-idamkan, lalu Marni berpikir untuk berdagang. Hal tersebut dapat dilihat dalam kutipan berikut.

Semalam, sepanjang ritual doa, dan ketika merebahkan diri di samping Simbok, aku sudah memikirkan semuanya. Aku akan bakulan, tapi tidak di pasar. Pasar ini sudah terlalu penuh dengan penjual. Segalanya sudah ada. Kehadiranku tak akan berpengaruh apa-apa.

Aku akan berjualan di jalan sepanjang pasar sampai ke Singget, lalu berkeliling dari rumah ke rumah yang ada di Singget. Siapa yang masih memilih jauh-jauh berjalan ke pasar kalau ada yang mengantar dagangan sampai ke pintu rumah? (hlm. 43-44).

Kutipan tersebut menunjukan ketidak puasan Marni dalam hidupnya, egonya terus saja berjalan dari dalam dirinya. Berawal dari entrok alu kini Marni menginginkan lebih dari sekedar entrok. Marni lalu memutuskan untuk berdagang dengan berjualan keliling sepanjang jalan menuju desa Singget. Dari kerja kerasnya membanting tulang hingga Marni menjadi orang kaya di Singget. Kekayaannya tersebut membuat egonya berjalan dan ingin menunjuan kepada warga Singget bahwa Marni yang dulunya tidak mempunyai apa-apa sekarang ia punya segalanya. Hal tersebut terlihat dari ia membeli televisi dan di Singget baru Marni dan pak lurah yang mempunyai. Hal tersebut dapat dilihat dalam kutipan sebagai berikut.

Televisi membuat kami mabuk, melupakan segala hal yang dialami pada siang hari. Lupa utang dan segala kebutuhan. Terbius kenikmatan kotak bergambar itu, Ibu lalu memilih untuk memilikinya sendiri. Kami bertiga, naik bus, pergi membeli TV ke Pasar Gede Madiun (hlm. 90).

Kutipan tersebut menunjukan ketika Marni membeli TV karena dia tidak mau kalah dengan pak lurah. Ego Marni untuk menjadi kaya tidak pernah ada habisnya hingga dia bertemu dengan Koh Cahyadi orang yang menjual perabotan elektronik di Pasar Gede Madiun saat Marni membeli TV. Koh Cahyadi mengajak Marni untuk beribadah di Gunung Kawi agar bisnis Marni semakin lancar. Hal tersebut terlihat dalam kutipan sebagai berikut.

Ia baru saja mendapat pengetahuan bahwa ada satu gunung di timur sana yang bisa memberikan kemakmuran pada orang-orang yang mendatanginya. Dan ia melihat sendiri bagaimana Koh Cahyadi memiliki toko yang besar dengan barang dagangan yang bukan remeh-remeh, tapi barang-barang mahal. Koh Cahyadi menawari Ibu untuk ikut dalam ziarahnya pada Jumat Legi yang jatuh minggu depan. Ibu langsung menyetujuinya. Mereka kini telah menjadi kawan dan saling memercayai (hlm. 93).

Kutipan tersebut menunjukan ketika Koh Cahyadi mengajak Marni untuk berziarah agar bisnisnya semakin lancar. Egonya tidak hanya menjadi seorang yang kaya raya, namun dia juga memiliki ego untuk menyekolahkan anaknya hingga sarjana agar Marni semakin dipandang oleh warga Singget karena dia orang pertama yang menyekolahkan anaknya hingga sarjana. Hal tersebut terlihat dalam kutipan sebagai berikut.

Lima ekor ayam telah disembelih. Tonah akan memasaknya menjadi panggang yang enak. Dia juga akan membuat lima tumpeng dan kulupan. Malam ini aku mau 
selamatan. Mengirim doa agar setelah ini jalannya juga dilancarkan. Dia mau kuliah, mau jadi sarjana. Pengestu, Gusti, biarkan aku yang pertama kali menyekolahkan anak sampai sarjana di Singget ini (hlm. 123).

Kutipan tersebut menunjukan bahwa Marni menjadi sombong dan angkuh. Hal tersebut terlihat ketika Marni ingin menyekolahkan anaknya sampai dengan sarjana namun dengan tujuan yang kurang baik. Dia menyobongkan hartanya supaya orang-orang di Singget tahu bahwa Marni memang seorang yang kaya raya. Setelah bertahun-tahun Rahayu pergi meninggalkan rumah, semua juga perlahan-lahan pergi meninggalkan Marni. Diawali dengan meninggalnya Teja, lalu disusul dengan perginya Tonah. Rumah menjadi sepi, sampai akhirnya musim tebu datang dan Marni bertemu dengan Marijo duda pegawai pabrik tebu. Hal tersebut terlihat dalam kutipan sebagi berikut.

Musim tebu selesai. Marijo masih tetap datang ke rumah. Sekarang dia tak lagi datang untuk ngopi, tapi katanya "Aku senang ngobrol karo kowe, Ni" Biasanya dia datang sore hari setelah pulang kerja, dan baru meninggalkan rumahku saat hampir tengah malam. Dari mengobrol, makan malam sammpai nonton TV bersama. Aku tak perduli meski ada beberapa yang sedang menonton TV. Kalaupun aku gendakan dengan Marijo juga tidak ada yang salah. Aku sudah tidak punya suami. Marijo, juga sudah tidak punya istri (hlm. 203).

Kutipan tersebut menunjukan ketika Marni dan Marij mulai menjalin hubungan. Hampir setiap hari Marijo datang ke rumah Marni dari sore hingga hampir tengah malam, superegonya berjalan dengan baik, sehingga ego Marni memperbolehkan Marijo setiap hari dari sore hingga tengah malam berada di rumahnya, tak perduli dengan omongan tetangga yang melihatnya. Setalah berlangsung beberapa hari, Marijo mulai berani menginap di rumah Marni. Marni sama sekali tidak melarang Marijo datang, bahkan Marni begitu gembira ketika Marijo datang ke rumahnya. Hal tersebut terlihat dalam kutipan sebagai berikut.

Marijo mulai menginap di rumah. Mungkin memang kami dua orang tua yang samasama tak tahu diri. Sudah sama-sama keriput, berperut buncit, tapi masih tergoda berahi. Tapi apakah orang-orang seperti kami tak berhak lagi merasakan kenikmatan dan kebahagiaan? Malam ini, Marijo membawakanku kembali ke pengalaman mendebarkan yang telah terjadi lebih dari dua puuh tahun lalu (hlm. 204).

Kutipan tersebut menunjukan ketika Marni begitu senang dan bahagia menjalin hubungan dengan Marijo. Mereka layaknya suami-istri yang hidup dalam satu rumah, dan Marni juga tak menghiraukan omongan tetangga. Ego Marni semakin memuncak ketika Marni dan Marijo berhubungan suami-istri di rumah Marni. Mereka tak ada canggung dan merasa dosa ketika melakukan tersebut. Marni begitu terlihat bahagia. Hal tersebut terlihat dalam kutipan sebagai berikut.

Malam ini, semuanya menjadi lain. Dimulai dengan rasa malu saat dia mulai membuka kain yang menutupi tubuhku yang kisut dan ngglambir ini, lalu aku tertawa pelan waktu melihat tubuh si Bagong tak lagi ditutupi selembar kain pun. Lalu dadaku berdebar kencang saat tangan berwarna coklat gosong itu menyentuh susuku yang sudah sangat kendor dan bergelantung seperti pepaya. Tiba-tiba saja ingatanku 
melayang. Seandainya memakai entrok sejak awal, pasti saat ini susuku mash kencang dan montok (hlm. 204).

Kutipan tersebut menunjukan ketika Marni melakukan hubungan suami-istri dengan Marijo padahal mereka belum menikah. Hal tersebut menunjukan ego Marni yang semakin tidak terkendali. Sudah berminggu-minggu Marijo menginap di rumah Marni, Marni sudah tidak menghiraukan omongan orang lain. Marni berpikir bahwa mereka sudah sama-sama tidak memiliki pasangan hidup, jadi boleh saja mereka melakukan hal itu. Hal tersebut terlihat dari kutipan berikut.

Tak terasa semakin banyak pakaian Marijo di rumah ini. Dia selalu membawa pakaian saat datang menginap, dan meninggalkan yang kotor waktu akan berangkat ke pabrik gula. Kebersamaan kami berakhir di saat pagi seperti ini. Saat dia dengan motornya menuju jalan raya ke timur, sementara aku dengan motornya menyusuri jalanan berdebu ke selatan menuju ke Pasar Ngranget. Di sore hari Marijo kembali datang, dan kami mengulang apa yang telah kami lakukan kemarin, dua hari lalu, atau beberapa minggu lalu (hlm. 205).

Kutipan tersebut menunjukan ketika Marni dan Marijo hidup berdua di rumah Marni. Marni merasa senang karena dia menemukan teman hidup yang baru ketika telah ditinggal Rahayu, Teja, dan Tonah. Meski dia menyalahi aturan karena mereka berdua belum menikah.

\subsection{Superego}

Meski Marni memiliki sifat yang begitu keras kepala dan seperti tidak ingin kalah dengan yang lainnya, namun Marni memiliki sifat yang begitu baik yang mau berbagi dengan lingkungan. Hal tersebut terlihat ketika Marni selalu berbagi dengan tetangga sekitar baik itu makanan maupun hanya sekedar untuk mempersilakan tetangganya menonton TV di rumahnya. Kebaikan Marni juga terlihat ketika dia kedatangan seorang anak kecil yang ternyata anak kandung Teja dengan Endang selingkuhan Teja. Meski dia tidak rela jika berbagi harta dengannya, namun hati nurani Marni menerima anak tersebut dengan lapang lapang dada jika ia ingin tinggal bersama Marni bahkan Marni juga mempersilakan anak tersebut untuk datang ke rumahnya jika dia lapar. Kebaikan Marni terhadap anak tersebut tak lain karna Marni iba dengan keadaan anak tersebut yang idak terurus dengan baik oleh ibunya, wajahnya yang begitu mirip dengan Teja juga membuat Marni begitu terbuka dengan anak tersebut. Kebaikan-kebaikan Marni terlihat dalam kutipan serikut ini.

Saat Pak Lurah dan Pak RT datang ke rumah esok hariya, Ibu bisa memberikan uang 50.000. dari simpanannya 25.000, bayaran dari Yu Ningsih dan Pak Pahing, dan tambahan dari cicilan orang-orang pada hari itu. Muka Pak Lurah langsung berseri saat menerima uang itu (hlm. 85).

Kutipan tersebut menunjukan ketika Marni menyubang kepada partai berbendera kuning untuk kampanye. Meski bukan dari keinginan Marni sedniri untuk memberikan uang tersebut, namun dengan Marni memberikan uang tersebut untuk dana kampanye dan hibungan warga, hal tersebut menunjukan superego Marni yang berjalan tidak hanya satu kali saja ia menyumbang, namun setiap kali ada kampanye, Marni menjadi donatur tetap untuk partai bergambar beringin tersebut. Hal tersebut terlihat dalam kutipan sebagai berikut. 
Sekarang ini saja, aku sudah ditagih sumbangan untuk kampanye. Mereka meminta 250.000. katanya untuk nyewa panggung lagi, sama seperti lima tahun lalu. Untung aku hidup tak lagi sesulit lima tahun lalu. Sekarang duit sebesar itu tak lagi hanya mengandalkan tagihan, tapi juga bisa memakai duit penjualan tebu yang akan dibayar oleh Pabrik Gula Purwodadi (hlm. 101).

Kutipan tersebut menunjukan ketika Marni menjadi langganan donatur untuk dana kampanye partai. Hampir setiap lima tahun sekali Marni dimintai uang untuk kampanye. Bukan hanya dana uang, namun juga Marni memberikan pikapnya dengan suka rela untuk dibawa ke kota untuk kapanye. Hal tersebut terlihat dalam kutipan berikut.

Hari kampanye besar-besaran itu tiba. Pagi-pagi Bejo sudah membawa pikap ke rumah Pak Lurah. Di sana orang-orang yang mau ikut arak-arakan berkumpul di lapangan Singget. Agak siang, aku berangkat ke lapangan. Bendera kuning dipasang mengelilingi lapangan. Orang-orang sudah ber-desakan mencari tempat yang paling dekat dengan panggung. Di panggung itu, nyantol uangku 250.000 (hlm. 114).

Kutipan tersebut menunjukan ketika Marni meminjamkan pikap yang dia punya untuk kampanye. Selain menyumbang untuk kegiatan dan hiburan yang diadakan oleh partai, Marni juga kerap membiarkan tetangga-tetangganya berada di rumahnya untuk sekadar menonton TV. Hal tersebut terlihat dalam kutipan sebagai berikut.

Setiap malam, rumah kami selalu dipenuhi orang. Kebetulan rumah kami dengan rumah Pak Lurah berjauhan. Kami di bagian Singget, Pak Lurah di bagian utara. Bagian utara yang selatan dipisahkan sungai. Selain Pak Wiji, orang-orang yang tinggal di selatan semuanya menonton televisi di rumah kami. Aku melihat Ibu dan Bapak senang (hlm. 95).

Kutipan tersebut menunjukan ketika rumah Marni yang selalu ramai oleh tetangga yang menonton TV di rumahnya. Selain itu Marni juga sangat ingin memakmurkan orang-orang di desa Singget. Marni memberikan upah buruh laki-laki tidak kurang dari cukup, dan Marni juga ingin memberi upah buruh perempuan dengan uang tidak dengan ketela seperti yang dilakukan oleh orang-orang. Hal tersebut terlihat dalam kutipan sebagai berikut.

Sayangnya tidak ada buruh perempuan di sini, betapapun ingin aku mengupaih mereka dengan uang sebesar buruh lelaki. Upah yang besarnya sama, tidak lebih kecil hanya karna dia perempuan, lebih-lebih hanya diupahi telo (hlm. 103).

Kalau Mbah Ibu Bumi Bapa Kuasa mengizinkan, semoga rezekiku dilancarkan, aku punya duit untuk membeli tanah lagi yang kutanami padi dan kacang. Akan aku pekerjakan perempuan-perempuan itu dan kuberi upah tak kurang daripada yang diterima suami-suami mereka (hlm. 103).

Kutipan tersebut menunjukan ketika Marni panen tebu dan membayar orang-orang untuk bekerja di ladangnya. Namun, di ladang tebu yang bekerja adalah kaum lelaki, sedangkan Marni ingin memperkerjakan kaum perempuan agar mereka dapat diupahi dengan uang, bukan lagi dengan telo. Selain Marni begitu baik dengan tetangganya yang meski mereka sering menggunjing dan memaki Marni, Marni juga begitu baik dengan temannya 
meski dia berada sedang berurusan dengan tentara dan Marni tau apa akibatnya jika beruruan dengan tentara. Hal tersebut terliht dalam kutipan berikut.

"Walah, kok tumben-tumbennya Koh Cahyadi mau nginep di sini? Ya pasti aku senang banget, Koh. Tapi apa nggak dicari sama anak istri nanti?” (hlm. 169).

Kutipan tersebut menunjukan ketika Marni dengan senang hati menerima Koh Cahyadi menginap di rumahnya untuk bersembunyi dari tentara-tentara itu. Ketika Koh Cahyadi berada di sana, berita duka menyelimuti Marni, Teja meninggal karena kecelakaan. Lalu Koh Cahyadi tertangkap oleh tentara dan Marni kembali sendiri. Dua tahun sudah Tejo meninggal, lalu Marni mengundang orang-orang untuk ikut selamatan di rumahnya. Hal tersebut terlihat dalam kutipan sebagai berikut.

Kusembelih seekor kambing untuk selamatan. Kupanggil tiga tukang masak dan satu orang pencuci piring untuk memasak Selamatan mendak pindo. Bukan lima orang atau 25 orang yang ku undang. Tapi 150 orang. Janda-janda yang tidak punya lakilaki di rumah mereka akan mendapat antaran makanan (hlm 189).

Kutipan tersebut menunjukan ketika Marni mengundang banyak orang dari umumnya. Marni ingin semua orang mendapat jatah, hal tersebut memperlihatkan bahwa Marni tidak egois dan begitu dermawan. Ketika acara tersebut berlangsung, datang seorang perempuan dengan membawa anak yang mengaku-aku sebagai anak Teja. Perempauan itu bernama Endang, dia meminta jatah untuk hidup anaknya. Hal tersebut terlihat dalam kutipan sebagai berikut.

"Tapi Teja mati tak punya apa-apa. Ini semua punyaku." Aku berusaha menahan amarah. "Kalau bocah ini mau ikut tinggal di sini ya monggo. Tapi kalu rumahnya mau diangkut ya tidak bisa." (hlm. 191).

Kutipan tersebut menunjukan ketika Marni memilih untuk merawat anak tersebut ketimbang berbagi harta dengan selingkuhan Teja. Marni merasa iba melihat anak yang tidak terurus oleh ibunya, sedangkan ibunya begitu cantik dan selalu berdandan dan wangi. Hal tersebutlah yang membuat Marni mau merawatnya. atau hari saat selamatan di tahun berikutnya kembali berlangsung, Marni melihat anak Teja yang sedang kelaparan. Hal tersebut terlihat dalam kutipan sebagai berikut.

Pandanganku berhenti pada seorang bocah yang sedang menyandar di pintu pawon. Bocah laki-laki itu menunggu temannya yang sedang merengek-rengek meminta makanan pada ibunya. Dia bukan anak orang Singget. Tapi aku seperti pernah melihatkan. Kuperhatikan anak itu lekat-lekat. Matanya, hidungnya, wajahnya mirip ... oh, dia anak sundal itu. Juga anak Teja. Dia sudah lebih besar dibandingkan saat kami bertemu waktu itu. Aku mengambil piring, lalu mengisinya dengan nasi dan gulai. Kuahnya yang terlalu banya menetes dari pinggir piring ke lantai. Aku berjalan pelanpelam ke pintu pawon, menjaga agar kuah tidak menetes terlalu banyak. Kuserahkan sepiring nasi gulai pada bocah laki-laki itu. Bocah itu langsung menerimanya dan makan dengan lahap. Tak malu atau ragu. Dia kelaparan (hlm. 208). 
Kutipan tersebut menunjukan ketika Marni memberikan makanan kepada bocah tersebut. Marni tidak merasa marah dan benci terhadap anak itu, meski anak itu adalah anak dari selingkuhan Teja. Setelah acara selesai, orang-orang pulang dengan membawa bungkusan makanan, Marni membungkuskan makanan untuk bocah itu. Hal tersebut terlihat dalam kutipan sebagai berikut.

Sengaja aku bungkuskan nasi dan lauk. Kuberikan anak itu ketika selamatan bubar. Dia pulang dengan membawa bungkusan paling banyak di antara orang-orang. Lalu kubisikan kalimat padanya, "Le, kalau lapar, mampir saja ke sini. Makan di sini" (hlm. 209).

Kutipan tersebut menunjukan ketika Marni dengan iklas memberikan makanan yang lebih banyak dari orang-orang dibawa pulang. Marni merasa sangat kasihan dengan bocah itu, karena bocah itu terlihat sangat tidak diurus oleh ibunya. Marni juga membisiskan kepada bocah itu untuk datang ke rumahnya setiap kali dia lapar. Selain memiliki hati yang begitu dermawan, Marni adalah seorang yang taat pada leluhurnya, ia sangat percaya dengan karma meski dia tidak tahu dosa. Hal tersebut terlihat dalam kutipan sebagai berikut.

Di dunia ini aku hanya takut mendapat karma. Merebut milik orang lain, lalu punyaku suatu saat diambil. Bersenang-senang setelah membuat orang lain menangis (hlm. 203)

Kutipan tersebut menunjukan ketika Marni begitu takut mendapatkan karma jika ia mengambil yang bukan miliknya.

\section{Simpulan}

Berdasarkan analisis data yang telah dilakukan, ditemukan adanya aspek kepribadian berdasarkan teori dari Sigmund Freud dalam tokoh utama Marni. Aspek id yang terdapat dalam tokoh Marni digambarkan sebagai seorang yang penuh dengan keinginan dalam dirinya. Keinginan yang asal mula hanya ingin memiliki entrok berubah menjadi keinginankeinginan lain yang berujung pada perbuatan Marni yang melanggar aturan, kodrat, dan norma. Aspek ego dalam tokoh Marni digambarkan ketika dia memaksakan kehendak menjadi seorang kuli panggul di pasar. Hal tersebut ditentang oleh simboknya dan juga teman-teman simbok seperti Mbah Noto dan Nyai Daimah karena dianggap melawan kodrat sebagai peempuan. Egonya kembali keluar ketika dia memutuskan untuk menjadi seorang bakul duit atau renternir. Keadaannya sebagai renternir dilawan keras oleh anaknya Rahayu, tetangga juga mengunjing Marni. Tidak sampai di situ, kepergian Teja, Rahayu, dan Tonah membuat Marni merasa kesepian. Hal tersebut membuat Marni menjadi melanggar norma dengan dia hidup satu atap dengan Marijo pegawai pabrik gula dan berhubungan layaknya suami istri. Aspek superego dalam tokoh Marni digambarkan ketika dia dengan suka rela membantu tetangganya dengan memberi pekerjaan kepada mereka meski tetangga Marni senang menggunjing dan memfitnah Marni tidak dihiraukannya.

\section{Daftar Pustaka}

Ingham, G. (2007). "The superego, narcissism and Great Expectations". International Journal Psychoanal. Vol. 88 (1). Pp 753-768.

Liang, Y. (2011). "The Id, Ego and Super-ego in Pride and Prejudice”. Canadian Center of 
Science and Education. Vol. 4 (2). Pp 57-69.

Madasari, O. (2010). Entrok. Jakarta: PT Gramedia Pustaka Utama.

Minderop, A. (2013). Psikologi Sastra: Karya Sastra,, Metode, Teori, dan Contoh Kasus. Jakarta: Yayasan Pustaka Obor.

Ratna, N.K. (2013). Teori, Metode, dan Telaah Penelitian Sastra. Yogyakarta: Pustaka Pelajar.

Semiun, Y. (2010). Teori Kepribadian dan Terapi Psikoanalitik Freud. Yogyakarta: Kanisius.

Sobur, A. (2013). Psikologi Umum dalam Lintasan Sejarah. Bandung: Pustaka Setia.

Wellek, R. \& Austin, W. (1993). Pengantar Teori Sastra. Terj. Melani Budianta. Jakarta: Gramedia.

Yusuf, L.N. Syamsu, Juntika Nurihsan. (2008). Teori Kepribadian. Bandung: Remaja Rosdakarya. 